\title{
Genetic Diversity Analysis of Some Barley Genotypes for Salt Tolerance Using SSR Markers
}

\author{
Samah A. Mariey ${ }^{1}$, Maher Noaman Mohamed ${ }^{1}$, Ismail A. Khatab ${ }^{2}$, Antar N. El-Banna ${ }^{2}$, \\ Amro Farouk Abdel Khalek ${ }^{3} \&$ Medhat Eraqy Al-Dinary ${ }^{4}$ \\ ${ }^{1}$ Barley Res. Dep., Field Crops Res. Institute, Agricultural Res. Center, Egypt \\ ${ }^{2}$ Dep. of Genetics, Faculty of Agriculture, Kafrelsheikh University, Egypt \\ ${ }^{3}$ Rice Res. Dep., Field Crops Res. Institute, Agricultural Res. Center, Sakha Expt. Res. Station., Egypt \\ ${ }^{4}$ Genetics Dep., Faculty of Agriculture, Tanta University, Egypt \\ Correspondence: Maher Noaman Mohamed, Barley Res. Dep., Field Crops Res. Institute, Agricultural Res. Center, \\ Egypt. E-mail: mahernoaman@yahoo.com
}

Received: March 19, 2013 Accepted: April 22, 2013 Online Published: June 15, 2013

doi:10.5539/jas.v5n7p12 URL: http://dx.doi.org/10.5539/jas.v5n7p12

\begin{abstract}
The aim of the present work was to evaluate the performance of 20 barley genotypes and find out the genetic diversity of these genotypes for salt tolerance using simple sequence repeats during two consecutive seasons; $2009 / 2010$ and 2010/2011. Twenty barley genotypes differed in their tolerance potentiality against salinity were planted in two screening field experiments at two locations; Sakha, North Egypt (as a control) and El-Serw (as saline site) to detect their tolerance to salt stress. They were planted in a randomized complete block design with three replicates. Results revealed that the Egyptian barley cultivars Giza 123, California Mariout and genotype no.12 (line 12 from Cyprus) were salt tolerant besides genotype no.9 (Saiko) giving a moderate salt tolerance response and they all exhibited the highest mean values for some traits such as heading date and plant height under saline condition. Out of ten primers used, only six primers (Bmac0209, Bmac0316, Scssr03907, Bmag770, HVM67 and HVHOTRI) generated clear patterns with high polymorphism. This six discriminatory primer pairs were used to evaluate the genetic diversity of salt tolerance in the 20 barley genotypes. Based on phylogenic trees the data from the dendrogram constructed with SSR markers showed four clusters. All the salt tolerant genotypes and some moderately salt tolerant genotypes were found in two closely related clusters, while all the sensitive genotypes and moderate ones were closely related in the other two clusters. It was concluded that those barley genotypes which showed salt tolerance could serve as potentially novel germplasm that could be exploited for the development of new breeding lines with high level of salinity tolerance and to accelerate genetic advancement in barley and better cost efficient compared to conventional and tedious screening procedures under saline field conditions.
\end{abstract}

Keywords: Simple Sequence Repeats, agronomic characteristics, Hordeum vulgare

\section{Introduction}

Salinity is a major abiotic stress affecting crops in Egypt and many other countries worldwide. More than 800 million hectares of land are globally salt affected, accounting for more than $6 \%$ of the total land area (Munns \& Tester, 2008). Egypt is one of the countries that suffer severe salinity problems in some areas of the country. For example, $33 \%$ of the cultivated land (Ghassemi et al., 1995), which comprises about 3\% of total land area in Egypt, is already salinized. The reduction in production of soils affected by salinity is about 30\% (El-Lakany et al., 1986).

Barley (Hordeum vulgare L.) $2 \mathrm{n}=2 \mathrm{x}=14$ is a crop with a great adaptation potential in many regions of the world. Growers can obtain a harvest in areas with low precipitations, mainly because this crop has advantages in aspects such as salt, drought, frost tolerance and the early period of development (Bennett \& Smith, 1976). It is an important crop, ranking the fourth crop in terms of production after wheat, rice and maize (Bengtsson, 1992). In terms of importance, barley is used mainly for animal feed, brewing malts and for human consumption in some countries. It is one of the most economic and important cereals grown under saline or partially reclaimed alkaline soils. 
Ahmed et al. (2001) found that barley genotypes significantly differed in plant height, biological yield and grain yield. They added that it was possible to identify some barley genotypes that could survive salt stress conditions. Taghipour and Salehi (2008) studying salt tolerance of Iranian barley (Hordeum vulgare L.) genotypes in seedling growth stages found significant differences among the genotype $\times$ stress interaction for all characteristics studied. Their results showed that seedling growth stages were decreased in all 12 barley varieties they have studied with increasing salinity level. Barley is also considered a model species for cereals due to its widely available genetic information (Hayes et al., 2002). The improvement of abiotic stress tolerance in barley depends largely on exploiting the available genetic variation in cultivated (Hordeum vulgare subsp. vulgare L.) and wild barley (H. vulgare subsp. spontaneum C. Koch.) (Robinson et al., 2000).

Microsatellite or simple sequence repeat (SSR) markers are very useful for plant breeding and genetic diversity studies for several reasons. SSR markers combine a number of advantages for practical applications, as they are co-dominant and multi-allelic, stably inherited, amenable to automation and high-throughput analysis, highly variable, and detect the highest level of polymorphism per locus (Röder et al., 2004).

They require only small amounts of sample DNA, are easy to amplify by polymerase chain reaction (PCR), are amenable to high-throughput analysis, and are largely co-dominantly inherited, multi-allelic, highly informative, and abundant in plant genomes (Powell et al., 1996). In barley, more than 775 microsatellites have been published (Varshney et al., 2007), and genetic maps based on microsatellites for all seven barley chromosomes are publicly available (Saghai-Maroof et al., 1994; Becker \& Heun, 1995; Liu et al., 1996; Struss \& Plieske, 1998; Ramsay et al., 2000; Varshney et al., 2007). Numerous studies on the analysis of genetic diversity in wild and cultivated barley have been conducted using SSRs makers (Saghai-Maroof et al., 1994; Russell et al., 1997, 2000; Struss and Plieske, 1998; Pillen et al., 2000; Macaulay et al., 2001; Ivandic et al., 2002; Hamza et al., 2004). Marker-assisted selection (MAS) is very efficient in backcross-assisted incorporation of single recessive resistance genes (Ordon et al., 2004) as well as in pyramiding non-linked resistance genes (Werner et al., 2005).

Few studies (Saker, 2005) have analyzed the pattern of genetic diversity by SSR markers within Egyptian barley. In the present research we used the SSR markers to investigate the genetic diversity among 20 Egyptian barley genotypes for salt tolerance.

\section{Materials and Methods}

The present field investigation was carried out at Sakha Research Farm (North of Egypt), Barley Research Department, Field Crops Research Institute; Agricultural Research Center during two growing seasons; 2009/2010 and 2010/2011. Laboratory work was carried out at the Central Laboratory for Environmental Studies, Kafr El-Sheikh University, Egypt. Two field experiments were carried out in this study; the first experiment was carried out during 2009/2010 season at two locations; El-Serw (as a saline soil) and Sakha (as a control non-saline soil) using 20 genotypes varied in their tolerance/sensitivity to salinity stress and were sown in a small scale as individual plants. The second experiment was carried out during 2010/2011 season at the same two locations; El-Serw and Sakha using the same twenty genotypes but sown in a larger scale in bigger plots $\left(1.6 \mathrm{~m}^{2}\right)$.

The selection criteria of these genotypes were based on pedigrees, origin of each genotype and the genotype performance, yield and its components, heading date and plant height (Eleuch et al., 2008), based on normal distribution curve. The present investigation also intended to study molecular markers associated with salt tolerance to be useful in barley future breeding programs. Moreover, to study the genetics of yield and yield components in the studied barley genotypes in order to detect the best genotypes, which are expected to be salt tolerant and to understand the genetic basis of key agronomic traits for the development of molecular markers.

\subsection{Barley Genotypes}

Twenty genotypes of barley (Hordeum vulgare L.) were selected from 48 genotypes based on their tolerance/sensitivity to salinity stress (Table 1). Barley genotypes were kindly provided by Sakha Barley Research Department, Field Crops Research Institute, Agricultural Research Center, Giza, Egypt. 
Table 1. Name, pedigree and origin of 20 barley cultivars and lines included in the second and third field experiments

\begin{tabular}{|c|c|c|c|c|}
\hline No & Genotype & & Origin & Pedigree \\
\hline 1 & Giza 121 & & Egypt & Baladi16/Gem. \\
\hline 2 & Giza 123 & & Egypt & Giza 117/FAO 86 \\
\hline 3 & Giza 124 & & Egypt & Giza 117/Bahteem 52// Giza 118/FAO 86 \\
\hline 4 & Giza 2000 & & Egypt & $\begin{array}{l}\text { Giza1 17/Bahteem52// Giza118/ FAO86 / 3/ } \\
\text { Baladi16/ Gem. }\end{array}$ \\
\hline 5 & Giza 132 & & Egypt & Rihane-05//AS 46/Aths*2Athe/ Lignee 686 \\
\hline 6 & CC89 & & Egypt & Selected from composite crosses \\
\hline 7 & Rihane3 (R3 & & ICARDA & As $46 / /$ Avt/Aths \\
\hline 8 & California Mariout (CM) & & Egypt & Selected landrace \\
\hline 9 & Saiko & & FRANCE & \\
\hline 10 & Beecher & & USA & Introduced to Egypt and named Giza 118 \\
\hline 11 & Dier Alla & & Jordan & \\
\hline 12 & $\mathrm{Mr} 25-84 / \mathrm{Att} / 3 / \mathrm{Mari} / \mathrm{Aths} / \mathrm{Bc}$ & Line1 & Cyprus & CYB-5235-0AP \\
\hline 13 & Alanda//Lignee527/Arar & Line2 & ICARDA & ICB89-0829-2LAP-3AP-0TR-3AP-0AP \\
\hline 14 & $\begin{array}{l}\text { Aths/Lignee686/5/Apm/RL/4/API/EB48 } \\
\text { 9-8-2-15-4//POR/U.SASK1766/3/ } \\
\text { CEL/CL }\end{array}$ & Line3 & ACSAD & ACS-B-10328-5IZ-3IZ-IIZ-0IZ \\
\hline 15 & CM67/4/Hma-02//11012-2/cm67/3/Arar & Line4 & ICARDA & ICB98-0238-0AP-7AP-0AP \\
\hline 16 & $\begin{array}{l}\text { Alanda01/5/c101021/4/CM67/ } \\
\text { U.Sask.1800//pro/CM67/3/dl70 }\end{array}$ & Line5 & ICARDA & $\begin{array}{l}\text { ICB } 890775-7 \text { AP-0AP-0AP-10AP-0AP-1A } \\
\text { P-0AP }\end{array}$ \\
\hline 17 & $\begin{array}{l}\text { Panniy/Salmas/5/Baca"s"/3/AC253// } \\
\text { C108887/C105761/4/JLB70-01 }\end{array}$ & Line6 & ACSAD & ACS-B-10824-10IZ-3IZ-1IZ-0IZ \\
\hline 18 & $\begin{array}{l}\text { Lignee527//NK1272/3/Nacha2// } \\
\text { Lignee640/Hma-01 }\end{array}$ & Line7 & ICARDA & $\begin{array}{l}\text { ICB95-0281-0AP-6AP-0AP-7TR-1TR-0A } \\
P\end{array}$ \\
\hline 19 & $\begin{array}{l}\text { M6476/Bon//JO/York/3/M5/Galt//As46/ } \\
\text { 4/Hj34-80/Astrix/5/Nk1272 }\end{array}$ & Line8 & ICARDA & ICB84-0156-0AP \\
\hline 20 & ACSAD618//Aths/Lignee686 & Line9 & ACSAD & ACS-B-9988-42IZ-1IZ-1IZ-0IZ \\
\hline
\end{tabular}

\subsection{Field Experiments}

Those twenty barley genotypes were grown in the field at two locations (Sakha non-saline and El-Serw saline soil) in two cropping seasons; 2009/2010 and 2010/2011 after taking soil samples from the experimental site at El-Serw to measure salinity level (EC). The twenty genotypes were planted in a randomized complete block design (RCBD) with three replicates each plot consisted of a genotype, which was planted in one row $2.5-\mathrm{m}$ long and $30-\mathrm{cm}$ apart in 2009/10 season and in plots of four rows 2.0-m long and 20-cm apart (plot area $=1.6 \mathrm{~m}^{2}$ ) with three replications in the 2010/11 growing season.

\subsection{Soil Samples}

Soil samples were taken before land preparation in two depths from the soil surface; i.e. $0-15 \mathrm{~cm}$ and $15-30 \mathrm{~cm}$. Chemical properties of the soil at El-Serw and Sakha locations for the two seasons; 2009/2010 and 2010/2011 are presented in Table 2. Field experimental samples were analyzed according to Piper (1950) and Black et al. (1965). 
Table 2. Chemical properties of soil samples from the field experiments site at El-Serw and Sakha locations during the two consecutive seasons, 2009/10 and 2010/11

\begin{tabular}{|c|c|c|c|c|}
\hline \multirow[b]{2}{*}{ Chemical properties } & \multicolumn{2}{|l|}{$2009 / 10$} & \multicolumn{2}{|l|}{$2010 / 11$} \\
\hline & El-Serw & Sakha & El-Serw & Sakha \\
\hline $\mathrm{pH}$ & 8.3 & 7.2 & 8.6 & 7.9 \\
\hline $\mathrm{ECe}\left(\mathrm{dsm}^{-1}\right)$ & 11.6 & 2.1 & 12.8 & 3.7 \\
\hline $\mathrm{CaCO}_{3} \%$ & 0.73 & 0 & 0.88 & 0 \\
\hline $\mathrm{SP} \dagger$ & 100 & 7.6 & 100 & 7.8 \\
\hline $\mathrm{SAR}+$ & 11.70 & - & 12.77 & - \\
\hline \multicolumn{5}{|c|}{ Soluble cations meq $100^{-1} \mathrm{~g}$ soil } \\
\hline $\mathrm{Ca}^{++}$ & 7.8 & 4.6 & 10.7 & 4.7 \\
\hline $\mathrm{Mg}^{++}$ & 12.5 & 2.5 & 14.7 & 5.7 \\
\hline $\mathrm{Na}^{++}$ & 95 & 14.4 & 45.6 & 14.8 \\
\hline $\mathrm{K}^{+}$ & 0.75 & 0.2 & 0.6 & 0.3 \\
\hline \multicolumn{5}{|c|}{ Soluble anions meq $100^{-1} \mathrm{~g}$ soil } \\
\hline $\mathrm{SO}_{4}$ & 18 & 6.2 & 36.3 & 7.1 \\
\hline $\mathrm{Cl}^{-}$ & 88 & 10.1 & 21.9 & 10.3 \\
\hline $\mathrm{HCO}_{3}$ & 11 & 5.5 & 5.3 & 4.1 \\
\hline $\mathrm{CO}_{3}$ & - & - & - & - \\
\hline
\end{tabular}

$\dagger$ SP : Soil Paste, $¥$ SAR: Sodium Absorpation Ratio.

\subsection{Studied Characteristics}

Five growth traits for the twenty barley genotypes were taken on ten individual plants that have been randomly taken from the central rows of each plot including seedling growth rate (\%), days to $50 \%$ heading, plant height $(\mathrm{cm})$, number of tillers $\mathrm{m}^{-2}$ and grain yield $\left(\mathrm{kg} \mathrm{m}^{-2}\right)$

\subsection{Statistical Analysis}

Data collected from the two seasons were statistically analyzed as a randomized complete block design (RCBD) using analysis of variance (ANOVA) for each season and over all the two locations in the two seasons 2009/10 and 2010/11 as a combined analysis. The mean values of genotypes and cultivars included in this trial were compared using Duncan's New Multiple Range Test (Duncan, 1955) (L.S.D.) at 0.05 level of probability. All statistical analyses were performed using the computer software MSTAT-C Computer Program according to (Snedecor \& Cochran, 1969).

\subsection{Microsatellite Markers, DNA Extraction and PCR Amplification}

Ten microsatellite primers from the published sequences of (Saghai-Maroof et al., 1994; Pillen et al., 2000; Ramsay et al., 2000; Karakousis, 2002) have been used for this study. They were on the average 18-24 bp in length. Primers' sequences, chromosomal location, size range, marker type and the reference are listed in Table 3. Genotyped markers were assigned using the Grain Genes data base (http://grain.jouy.inra.fr/cgibin/graingenes/browse.cgi) (Kleinhofs \& Graner, 2001). 
Table 3. Barley SSRs primers, their sequences, the chromosomal location (Von Korff et al., 2004) of derived loci, size range, marker type, motif and the reference

\begin{tabular}{|c|c|c|c|c|c|c|}
\hline No & Marker & PCR primers & Chromosome & Size & Type & Reference \\
\hline 1 & HVHOTR1 & $\begin{array}{l}\text { F:ATGAGCAGTCTTGTCTTAACC } \\
\text { R:AGTTGGTCGCTAGATCTTATG }\end{array}$ & $2 \mathrm{H}$ & 165 & SSR & $\begin{array}{l}\text { Hayden et. } \\
\text { al. (2006) }\end{array}$ \\
\hline 2 & HVM67 & $\begin{array}{l}\text { F:GTCGGGCTCCATTGCTCT } \\
\text { R:CCGGTACCCAGTGACGAC }\end{array}$ & $4 \mathrm{H}$ & 116 & SSR & $\begin{array}{l}\text { Sato K et al. } \\
(2009)\end{array}$ \\
\hline 3 & HVAMY2 & $\begin{array}{l}\text { F:CTGTAAGTGAGACAATCGACA } \\
\text { R:CAGTTGAACCCCTGAAAG }\end{array}$ & $7 \mathrm{H}$ & 134 & SSR & $\begin{array}{l}\text { Ramsy et al. } \\
(2000)\end{array}$ \\
\hline 4 & HVHVA1 & $\begin{array}{l}\text { F:CATGGGAGGGGACAACAC } \\
\text { R:CGACCAAACACGACTAAAGGA }\end{array}$ & $1 \mathrm{H}$ & 136 & SSR & $\begin{array}{l}\text { Ramsy et al. } \\
(2000)\end{array}$ \\
\hline 5 & scssr0013 & $\begin{array}{l}\text { F: GGTAAGGAGTGGGTCTCAGG } \\
\text { R:CAAGCAGATGCAACTACACC }\end{array}$ & $6 \mathrm{H}$ & 168 & $\begin{array}{l}\text { SSR, } \\
\text { SNP }\end{array}$ & $\begin{array}{l}\text { Hearnden et } \\
\text { al. }(2007)\end{array}$ \\
\hline 6 & scssr0397 & $\begin{array}{l}\text { F: CTCCCATCACACCATCTGTC } \\
\text { R: GACATGGTTCCCTTCTTCTTC }\end{array}$ & $5 \mathrm{H}$ & Unknown & $\begin{array}{l}\text { SSR, } \\
\text { SNP }\end{array}$ & $\begin{array}{l}\text { Hearnden et } \\
\text { al. }(2007)\end{array}$ \\
\hline 7 & Bmac0316 & $\begin{array}{l}F^{\prime}: \text { ATGGTAGAGGTCCCAACTG } \\
\text { R :ATCACTGCTGTGCCTAGC }\end{array}$ & $6 \mathrm{H}$ & 135 & SSR & $\begin{array}{l}\text { Ramsy et al. } \\
(2000)\end{array}$ \\
\hline 8 & Bmac0209 & $\begin{array}{l}\text { F: CTAGCAACTTCCCAACCGAC } \\
\text { R:ATGCCTGTGTGTGGACCAT }\end{array}$ & $3 \mathrm{H}$ & 176 & SSR & $\begin{array}{l}\text { Varshney et } \\
\text { al. (2007) }\end{array}$ \\
\hline 9 & Bmag770 & $\begin{array}{l}\text { F: AAGCTCTTTCTTGTATTCGTG } \\
\text { R: GTCCATACTCTTTAACATCCG }\end{array}$ & $1 \mathrm{H}$ & 158 & SSR & $\begin{array}{l}\text { Ramsy et al. } \\
(2000)\end{array}$ \\
\hline 10 & Bmag0387 & $\begin{array}{l}\text { F:CGATGACCATTGTATTGAAG } \\
\text { R: CTCATGTTGATGTGTGGTTAG }\end{array}$ & $5 \mathrm{H}$ & 123 & SSR & $\begin{array}{l}\text { Varshney et } \\
\text { al. }(2007)\end{array}$ \\
\hline
\end{tabular}

$\mathrm{F}=$ Forward, $\mathrm{R}=$ Reverse.

Genomic DNA of the 20 barley genotypes was extracted from leaves isolated using CTAB method adapted by (Doyle \& Doyle, 1990). The quantification of DNA was confirmed by agarose gel electrophoresis (2\%) in 1 x TBE buffer against $100 \mathrm{bp}$ DNA Ladder as a size marker. Polymerase chain reaction (PCR) amplification was prepared in volume of $25 \mu \mathrm{l}$ using $40 \mathrm{ng}$ genomic DNA, $2 \mu \mathrm{mol} \mathrm{dNTP}, 25 \mathrm{mM} \mathrm{MgCl}_{2}, 10$ pmol of each primer (forward and reverse), $5 \mathrm{U}$ Taq polymerase.). PCR cycling was carried out as the following program; one cycle at $95^{\circ} \mathrm{C}$ for 5 min., then 35 cycles were performed as follows: $1 \mathrm{~min}$. at $95^{\circ} \mathrm{C}$ for denaturation, $45 \mathrm{sec}$. at (based on primer almost $54 \sim 56^{\circ} \mathrm{C}$ ) for annealing and $30 \mathrm{sec}$. at $72^{\circ} \mathrm{C}$ for extension. Reaction was incubated at $72^{\circ} \mathrm{C}$ for $7 \mathrm{~min}$ then at $4{ }^{\circ} \mathrm{C}$ for keeping.

\subsection{Statistical Analysis and Data Scoring}

The amplified bands from SSR were scored under the heading of total scorable fragments. Amplification profiles of the 20 barley genotypes were compared with each other and bands of DNA fragments were scored as a binary data where presence (1) or absences (0), for all accessions and then converted to a genetic similarity (GS) matrix. The data were used to estimate genetic similarity (GS) on the basis of the number of shared amplification products (Nei \& Li, 1979). The coefficients were calculated by the following statistical equation:

$$
\mathrm{F}=2 \mathrm{~N}_{\mathrm{xy}} /\left(\mathrm{N}_{\mathrm{x}}+\mathrm{N}_{\mathrm{y}}\right)
$$

Where, $\mathrm{F}$ is the similarity coefficient in which $\mathrm{Nx}$ and $\mathrm{Ny}$ are the number of fragments in genotypes $\mathrm{x}$ and $\mathrm{y}$, respectively, where Nxy is the number of fragments shared by the two genotypes (Lynch, 1990).

Phylogenetic trees were constructed based on similarity matrix obtained with neighbor joining (NJ) method using Jaccard formula $\mathrm{d}_{\mathrm{jk}}=\mathrm{M} /(\mathrm{M}+\mathrm{N})$. The relationships among genotypes were displayed as dendrogram using the NTSYSpc 2.01 software package (Rohlf, 1998). Finally, percent polymorphism was calculated using the formula,

$$
\text { Percent polymorphism }=\frac{\text { Total number of polymorphic bands }}{\text { Total number of bands }} \times 100
$$




\section{Results and Discussion}

Data were classified into two major topics; field screening and molecular analysis:

\subsection{Field Screening}

Generally, field screening for salinity tolerance remains the main tool, despite its limitation of time required and environmental dependency. However, many potential criteria or traits have been proposed for field screening.

The significance and the mean performance of the 20 barley genotypes were calculated for the five studied characteristics for the twenty genotypes which were selected from 48 genotypes and were grown in the field at two locations (Sakha non-saline and El-Serw saline soil) in two cropping season 2009/2010 and 2010/2011.

\subsubsection{Seedling Rate (SR)}

Seedling rate of each genotype was estimated and data were analyzed and tabulated in Table 4 . The data showed high significant differences among all 20 genotypes at seedling stage at both locations and their combined during the 2009/10 season. Data in Table 5 indicate that the mean values of the highest germination of seedling stage were obtained from barley cultivar no.2 (Giza 123) and barley cultivar no. 8 (California Mariout) which gave 100\% germination at both locations and in their combined, whereas under Sakha conditions, about seven barley genotypes gave $100 \%$ germination. On the other hand, barley genotype no. 18 gave the lowest mean value of the germination under El-Serw (26.7\%), (66.7\%) under Sakha and about (46.7\%) in the combined between the two locations followed by barley cultivar no.5 (Giza 132) giving (26.7\%) under El-Serw conditions, (73.3\%) under Sakha and $(50.0 \%)$ in their combined. Moreover, in 2010/11 growing season, the data in Table 8 show high significant differences among all 20 genotypes at both locations; and their combined analysis. Data in Table 9 indicate that the mean values of the highest germination of seedling stage were obtained from barley cultivar no. 2 (Giza 123) and no.8 (California Mariout), whereas barely genotype no.12 gave the same rate of germination at both locations (El-Serw and Sakha) and in their combined recording 78.3, 100 and 89.2\% germination, respectively. At Sakha, about eight barley genotypes gave $100 \%$ germination. On the other hand, barley genotype no.17 gave the lowest mean value of the germination at El-Serw $(8.3 \%)$, and about $(47.5 \%)$ in the combined between the two locations, while barley genotype no.5 (Giza 132) and barley genotype no.11 (Dier Alla) both gave the same value (80.0\%) at Sakha. Those results were similar to the findings of (Naseer et al., 2001; Taghipour \& Salehi, 2008). High significant interaction (GxL) between the two locations (L) and genotypes (G) for seedling rate was detected (Table 9). Those results were similar to the findings reported by (Naseer et al., 2001; Taghipour \& Salehi, 2008) who reported that salt tolerance at the seedling stage is important because the initial plant stand affects the final production in growth stages. High significant interaction (GxL) between the two locations (L) and Genotypes (G) for seedling rate was detected (Table 5). Those results were similar to those obtained by (Taghipour $\&$ Salehi, 2008) who found that there were significant differences among the genotype $\times$ stress interaction for seedling growth.

\subsubsection{Days to Heading (DH)}

Concerning days to heading (DH), data presented in Table 4 show high significant differences for this characteristic among barley genotypes and between the two locations and their combined during the 2009/2010 growing season. Results in Table 5 show the means for DH of the 20 barley genotypes under study at the two locations. The results showed that genotype no. 12 was the earliest at the two locations; El-Serw and Sakha (79.3 and 89.3 days), respectively. In addition, this genotype was the earliest across the two locations having an average of 84.3 days. On the other hand, the latest barley cultivar was no.11. (Dier Alla) with average values of (89.3 days) at El-Serw, while under Sakha barley cultivar no.5 (Giza 132) was the latest ( 96.0 days) followed by barley cultivar no.11 (Dier Alla), which recorded (94.0 days). In addition, the same barley cultivar genotype no. 11 (Dier Alla) headed later over the two locations (91.7 days) as well as in the second season, 2010/11. Data of the appearance of $50 \%$ of spikes from the sheath (known as days to heading) are presented in Table 8 showing high significant differences for this characteristic among the 20 barley genotypes at both locations; saline (El-Serw) and non-saline (Sakha) and their combined during the 2010/11 growing season. Results in Table 9 show the means of DH of the 20 barley genotypes under study for the two locations and their combined. Results show that barley cultivar no.9 (Saiko) was the earliest at the two locations; El-Serw and Sakha (87.7 and 96.3 days), respectively. In addition, this genotype was the earliest across the two locations having an average of 92.0 days. On the other hand, the latest barley genotype was no. 17 with average of 101.7 days at El-Serw, while at Sakha barley genotype no.10 (Beecher) and no.11 (Dier Alla) were both the latest genotypes and had the same value recording (105.7 days). In addition, the same two barley cultivars no.10 (Beecher) and no. 11 (Dier Alla) headed later over the two locations with mean values of (102.2 and 102.3 days), respectively. These results are in agreement with those reported by 
(Ellis et al., 2000; Mariey, 2004; Oraby et al., 2005; Eleuch et al., 2008). Data in Table 9 show significant interaction $(\mathrm{LxG})$ between the two locations $(\mathrm{L})$ and genotypes $(\mathrm{G})$ for heading date.

Table 4. Mean squares of seedling rate, days to heading, and plant height for 20 barley genotypes under El-Serw, Sakha conditions and their combined in the first experiment during 2009/2010 growing season

\begin{tabular}{|c|c|c|c|c|c|c|c|c|c|c|}
\hline \multirow{3}{*}{ S.O.V. } & \multirow{3}{*}{$\mathrm{DF}$} & \multicolumn{3}{|l|}{$\begin{array}{l}\text { Seedling rate } \\
\text { (days) }\end{array}$} & \multicolumn{3}{|c|}{$\begin{array}{l}\text { Days to heading } \\
\text { (days) }\end{array}$} & \multicolumn{3}{|c|}{$\begin{array}{l}\text { Plant height } \\
(\mathrm{cm})\end{array}$} \\
\hline & & \multicolumn{2}{|l|}{ Location } & \multirow{2}{*}{ 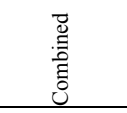 } & \multicolumn{2}{|l|}{ Location } & \multirow{2}{*}{ 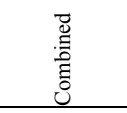 } & \multicolumn{2}{|l|}{ Location } & \multirow{2}{*}{$\begin{array}{l}\text { ठే } \\
\text { हี } \\
\text { ப் }\end{array}$} \\
\hline & & El-Serw & Sakha & & El-Serw & Sakha & & El-Serw & Sakha & \\
\hline Rep. & 2 & 206.6 & 46.66 & 210 & 125 & $6.87^{* * *}$ & $3.56^{*}$ & 75.25 & 4.74 & 29.72 \\
\hline Genotype & 19 & $1730.17 * * *$ & $394.39 * * *$ & $1749.29 * * *$ & $22.203 * * *$ & $48.76^{* * *}$ & $22.885^{* * *}$ & $66.107 * *$ & $365.828 * * *$ & $330.81 * * *$ \\
\hline Location & 1 & & & $16803.3^{* * *}$ & & & $2585.40^{* * *}$ & & & $19364.6^{* * *}$ \\
\hline Gen x Loc. & 19 & & & $375.26^{* * *}$ & & & $11.075^{* * *}$ & & & $101.119^{* * *}$ \\
\hline Error & 78 & & & 76.666 & & & 0.9002 & & & 16.121 \\
\hline
\end{tabular}

$*$, ** and $* * *$ indicate significance at $\mathrm{P} \leq 0.05,0.01$, and 0.001 .

Table 5. Mean performance of seedling rate, days to heading, and plant height as affected by 20 barley genotypes under El-Serw and Sakha conditions and their combined in the first experiment during 2009/10 growing season

\begin{tabular}{|c|c|c|c|c|c|c|c|c|c|}
\hline \multirow{2}{*}{ Genotype } & \multicolumn{3}{|c|}{ Seedling rate $(\%)$} & \multicolumn{3}{|c|}{ Days to heading (days) } & \multicolumn{3}{|c|}{ Plant height $(\mathrm{cm})$} \\
\hline & El-Serw & Sakha & Combined & El-Serw & Sakha & Combined & El-Serw & Sakha & Combined \\
\hline 1 & 86.7 & 100.0 & 93.3 & 81.0 & 91.3 & 86.2 & 58.2 & 96.7 & 77.4 \\
\hline 2 & 100.0 & 100.0 & 100.0 & 79.7 & 89.3 & 84.5 & 61.3 & 100.5 & 80.9 \\
\hline 3 & 60.0 & 86.7 & 73.3 & 80.0 & 90.7 & 85.3 & 59.4 & 86.2 & 72.8 \\
\hline 4 & 86.7 & 100.0 & 93.3 & 81.3 & 93.0 & 87.2 & 60.4 & 77.3 & 68.8 \\
\hline 5 & 26.7 & 73.3 & 50.0 & 80.3 & 96.0 & 88.2 & 46.5 & 58.9 & 52.7 \\
\hline 6 & 73.3 & 86.7 & 80.0 & 80.7 & 90.7 & 85.7 & 49.7 & 75.3 & 62.5 \\
\hline 7 & 86.7 & 100.0 & 93.3 & 81.7 & 92.0 & 86.8 & 57.2 & 79.0 & 68.1 \\
\hline 8 & 100.0 & 100.0 & 100.0 & 80.0 & 90.0 & 85.0 & 58.7 & 88.3 & 73.5 \\
\hline 9 & 93.3 & 100.0 & 96.7 & 82.3 & 93.7 & 88.0 & 55.8 & 90.7 & 73.2 \\
\hline 10 & 40.0 & 86.7 & 63.3 & 88.0 & 93.7 & 90.8 & 49.5 & 74.1 & 61.8 \\
\hline 11 & 46.7 & 73.3 & 60.0 & 89.3 & 94.0 & 91.7 & 54.5 & 82.0 & 68.2 \\
\hline 12 & 93.3 & 100.0 & 96.7 & 79.3 & 89.3 & 84.3 & 62.2 & 86.9 & 74.5 \\
\hline 13 & 73.3 & 100.0 & 86.7 & 83.3 & 91.0 & 87.2 & 56.4 & 82.1 & 69.2 \\
\hline 14 & 66.7 & 93.3 & 80.0 & 81.0 & 90.0 & 85.5 & 59.3 & 79.0 & 69.2 \\
\hline 15 & 53.3 & 100.0 & 76.7 & 81.0 & 91.0 & 86.0 & 53.7 & 68.6 & 61.1 \\
\hline 16 & 46.7 & 73.3 & 60.0 & 87.7 & 90.7 & 89.2 & 52.0 & 69.7 & 60.8 \\
\hline 17 & 40.0 & 86.7 & 63.3 & 82.0 & 91.7 & 86.8 & 51.3 & 73.1 & 62.2 \\
\hline 18 & 26.7 & 66.7 & 46.7 & 84.0 & 92.3 & 88.2 & 47.3 & 66.7 & 57.0 \\
\hline 19 & 86.7 & 100.0 & 93.3 & 84.7 & 92.0 & 88.3 & 56.8 & 99.4 & 78.1 \\
\hline 20 & 66.7 & 100.0 & 83.3 & 81.7 & 92.3 & 87.0 & 58.7 & 82.6 & 70.7 \\
\hline Average & 67.7 & 91.3 & 79.5 & 82.5 & 91.7 & 87.1 & 55.4 & 80.9 & 68.1 \\
\hline L.S.D. 0.05 & 16.06 & 12.87 & 10.06 & 1.59 & 1.37 & 1.09 & 7.71 & 5.12 & 4.62 \\
\hline C.V.\% & 14.36 & 8.53 & 11.01 & 1.17 & 0.89 & 1.08 & 8.41 & 3.84 & 5.89 \\
\hline
\end{tabular}




\subsubsection{Plant Height}

In 2009/10 growing season, plant height of the 20 barley genotypes showed significant differences among the genotypes under study. Data in Table 4 show high significant differences at the two locations and their combined analysis. The mean performances of the 20 barley genotypes for plant height are shown in Table 5. Results indicate that barley genotype no. 12 was ranked first for plant height $(62.2 \mathrm{~cm})$ under El-Serw conditions, and means of this trait clearly indicated that the Egyptian barley cultivar genotype, Giza 123 was the tallest at each individual locations and their combined recording $61.3,100.5$ and $80.9 \mathrm{~cm}$, respectively. On the other hand, the shortest genotype was recorded by genotype no.5 at each individual location and their combined recording 46.5, 58.9 and $52.7 \mathrm{~cm}$, respectively, followed by genotype no. 18 at each individual location and their combined recording 47.3, 66.7 and $57.6 \mathrm{~cm}$, respectively. While in season 2010/11, plant height of the 20 barley genotypes showed significant differences among all genotypes under study. Data in Table 8 show high significant differences at the two locations and their combined. The mean performances of the 20 barley genotypes for plant height under the study are shown in Table 9. Results indicate that barley genotype no. 19 was ranked first for plant height (89.3 and $105.8 \mathrm{~cm}$ ), at El-Serw location and the combined, respectively. Mean values of this trait clearly indicate that the Egyptian barley cultivar no.2 (Giza 123) was the tallest at Sakha location recording $124.3 \mathrm{~cm}$. On the other hand, the shortest genotype was recorded by barley cultivar no.6 (CC 89) at El-Serw location $(67.3 \mathrm{~cm})$, while barley genotype no.17 was the shortest at each of Sakha location and in the combined recording 100.7 and $87.6 \mathrm{~cm}$, respectively. These results are in agreement with those recorded by (Ahmed et al., 2001; Mariey, 2004). High Significant interaction $(\mathrm{GxL})$ between the two locations $(\mathrm{L})$ and genotypes $(\mathrm{g})$ for plant height was detected (Table 9).

\subsubsection{Number of Tillers Plant ${ }^{-1}$}

Concerning number of tillers plant ${ }^{-1}$, data in Table 6 show high significant differences among the 20 barley genotypes at the two locations; El-Serw and Sakha and their combined during 2009/10 growing season. The results of mean performance as shown in Table 7, revealed that at El-Serw location and in the combined analysis, barley cultivar no. 6 (CC89) had the lowest value for number of tillers plant ${ }^{-1}\left(6.4\right.$ and 8.1 tillers plant $\left.{ }^{-1}\right)$, respectively, whereas at Sakha location barely genotype no. 17 was recorded as the lowest genotype for number of tillers plant ${ }^{-1}$ $\left(8.2\right.$ tillers plant $\left.^{-1}\right)$. The same genotype gave the lowest number at the combined analysis between the two locations $\left(8.1\right.$ tillers plant $\left.^{-1}\right)$. On the other hand, barley cultivar no.1 (Giza 121) ranked first for number of tillers plant ${ }^{-1}$ at both locations and in their combined, while barley genotype no. 12 gave the highest value for number of tillers plant ${ }^{-1}$ at Sakha location (18.8 tillers plant $\left.{ }^{-1}\right)$. The differences among genotypes' ability to produce suitable number of tillers or tillers containing spikes might be attributed to its genetically constitutions. Regarding number of tillers $\mathrm{m}^{-2}$ in the 2010/11 growing, data in Table 10 show high significant differences among the 20 barley genotypes at the two locations; El-Serw and Sakha and their combined. Data of the mean performance as shown in Table 11, reveal that at El-Serw location and in their combined, barley genotype no. 5 (Giza 132) had the lowest value for number of tillers $\mathrm{m}^{-2}$ (243.0 and 313.5 tillers $\left.\mathrm{m}^{-2}\right)$, respectively, whereas at Sakha location, barely genotype no. 18 recorded the lowest value of number of tillers $\mathrm{m}^{-2}\left(353.0\right.$ tillers $\mathrm{m}^{-2}$ ). On the other hand, barley genotype no.1 (Giza 121) gave the highest value for number of tillers $\mathrm{m}^{-2}$ at Sakha and in their combined (597.0 and 517.0 tillers $\mathrm{m}^{-2}$ ), while barley cultivar no. 2 (Giza 123) gave the highest value for number of tillers $\mathrm{m}^{-2}$ at El-Serw location $\left(467.0\right.$ tillers $\mathrm{m}^{-2}$ ). These results were supported by the results reported by (Ahmed et al., 2003; Mariey, 2004). The combined analysis (Table 11) showed high significant effect of the interaction between locations (L) and genotypes (GxL) for the number of tillers $\mathrm{m}^{-2}$. 
Table 6. Mean squares of No. tillers and grain yield as affected by 20 barley genotypes under El-Serw, Sakha and their combined first experiment during 2009/10 growing season

\begin{tabular}{|c|c|c|c|c|c|c|c|}
\hline \multirow{3}{*}{ S.O.V. } & \multirow{3}{*}{$\mathrm{DF}$} & \multicolumn{3}{|c|}{ No. Tillers plant $^{-1}$} & \multicolumn{3}{|l|}{ Grain yield } \\
\hline & & \multicolumn{2}{|l|}{ Location } & \multirow{2}{*}{ 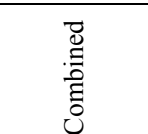 } & \multicolumn{2}{|l|}{ Location } & \multirow{2}{*}{ 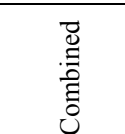 } \\
\hline & & El-Serw & Sakha & & El-Serw & Sakha & \\
\hline Rep. & 2 & 2.53 & 0.68 & 0.38 & 0.81 & 4.014 & 1.17 \\
\hline Genotype & 19 & $14.832 * * *$ & $25.49^{* * *}$ & $33.5405^{* * *}$ & $45.5913 * * *$ & $134.37 * * *$ & $141.45^{* * *}$ \\
\hline Location & 1 & & & $259.89 * * *$ & & & $894.34 * * *$ \\
\hline Gen x Loc. & 19 & & & $6.7889^{* * *}$ & & & $38.51 * * *$ \\
\hline Error & 78 & & & 1.2349 & & & 2.4580 \\
\hline
\end{tabular}

$* * *$ indicate significance at $\mathrm{P} \leq 0.001$.

Table 7. Mean of No. tillers and grain yield as affected by 20 barley genotypes under El-Serw, Sakha and their combined in the first experiment during 2009/10 growing season

\begin{tabular}{|c|c|c|c|c|c|c|}
\hline \multirow{2}{*}{ Genotype } & \multicolumn{3}{|c|}{ No. Tillers plant ${ }^{-1}$} & \multicolumn{3}{|c|}{ Grain yield $\left(\right.$ g plant $\left.^{-1}\right)$} \\
\hline & El-Serw & Sakha & Combined & El-Serw & Sakha & Combined \\
\hline 1 & 16.3 & 16.4 & 16.3 & 14.4 & 36.1 & 25.3 \\
\hline 2 & 13.1 & 17.4 & 15.3 & 18.7 & 32.3 & 25.5 \\
\hline 3 & 7.9 & 9.6 & 8.7 & 12.6 & 15.8 & 14.2 \\
\hline 4 & 8.3 & 10.6 & 9.4 & 13.8 & 14.5 & 14.1 \\
\hline 5 & 9.1 & 9.6 & 9.4 & 13.0 & 13.6 & 13.3 \\
\hline 6 & 6.4 & 9.7 & 8.1 & 7.2 & 12.2 & 9.7 \\
\hline 7 & 9.7 & 14.9 & 12.3 & 11.6 & 17.0 & 14.3 \\
\hline 8 & 10.5 & 13.7 & 12.1 & 13.6 & 15.0 & 14.3 \\
\hline 9 & 11.1 & 11.3 & 11.2 & 10.6 & 12.1 & 11.4 \\
\hline 10 & 10.2 & 11.0 & 10.6 & 5.8 & 12.1 & 9.0 \\
\hline 11 & 9.3 & 10.5 & 9.9 & 6.8 & 12.3 & 9.5 \\
\hline 12 & 12.2 & 18.8 & 15.5 & 15.3 & 18.8 & 17.1 \\
\hline 13 & 10.0 & 14.6 & 12.3 & 12.9 & 13.1 & 13.0 \\
\hline 14 & 10.6 & 15.7 & 13.1 & 7.2 & 10.7 & 8.9 \\
\hline 15 & 9.9 & 14.1 & 12.0 & 6.0 & 15.4 & 10.7 \\
\hline 16 & 9.9 & 13.0 & 11.5 & 6.4 & 13.3 & 9.8 \\
\hline 17 & 8.1 & 8.2 & 8.1 & 6.9 & 12.1 & 9.5 \\
\hline 18 & 6.9 & 14.0 & 10.5 & 6.4 & 11.5 & 9.0 \\
\hline 19 & 8.2 & 10.7 & 9.4 & 6.0 & 14.3 & 10.1 \\
\hline 20 & 9.8 & 12.6 & 11.2 & 9.3 & 11.3 & 10.3 \\
\hline Average & 9.9 & 12.8 & 11.3 & 10.2 & 15.7 & 12.9 \\
\hline L.S.D. 0.05 & 9.9 & 1.72 & 1.27 & 1.71 & 3.21 & 1.80 \\
\hline C.V.\% & 11.56 & 8.13 & 9.79 & 10.14 & 12.41 & 12.11 \\
\hline
\end{tabular}


Table 8 . Mean squares of seedling rate, days to heading, and plant height as affected by 20 barley genotypes under El-Serw, Sakha and their combined in the second experiment during 2010/11 growing season

\begin{tabular}{|c|c|c|c|c|c|c|c|c|c|c|}
\hline \multirow{3}{*}{ S.O.V. } & \multirow{3}{*}{$\mathrm{DF}$} & \multicolumn{3}{|l|}{$\begin{array}{l}\text { Seedling rate } \\
\text { (days) }\end{array}$} & \multicolumn{3}{|c|}{$\begin{array}{l}\text { Days to heading } \\
\text { (days) }\end{array}$} & \multicolumn{3}{|l|}{$\begin{array}{l}\text { Plant height } \\
(\mathrm{cm})\end{array}$} \\
\hline & & \multicolumn{2}{|l|}{ Location } & \multirow{2}{*}{ 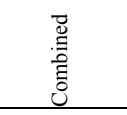 } & \multicolumn{2}{|l|}{ Location } & \multirow{2}{*}{ 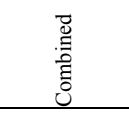 } & \multicolumn{2}{|l|}{ Location } & \multirow{2}{*}{$\begin{array}{l}\vec{\Xi} \\
. \overline{0} \\
\text { है } \\
\end{array}$} \\
\hline & & El-Serw & Sakha & & El-Serw & Sakha & & El-Serw & Sakha & \\
\hline Rep. & 2 & $386.25 * *$ & $21.666 \mathrm{NS}$ & $193.95^{*}$ & $59.8166^{* *}$ & $33.616^{* * *}$ & $91.525^{* * *}$ & $43.1166 \mathrm{NS}$ & $177.45^{*}$ & $192.508^{* *}$ \\
\hline Genotype & 19 & $738.135^{* * *}$ & $171.491 * * *$ & $588.804 * * *$ & $27.5956 * * *$ & $17.389 * * *$ & $32.0328 * * *$ & $96.8026^{* * *}$ & $134.34 * * *$ & $134.408^{* * *}$ \\
\hline Location & 1 & & & $22550.2 * * *$ & & & $837.408 * * *$ & & & $1159.40^{* * *}$ \\
\hline Gen $x$ Loc. & 19 & & & $320.822 * * *$ & & & $12.952 * *$ & & & $96.741 * * *$ \\
\hline Error & 78 & & & 51.6506 & & & 5.6019 & & & 34.722 \\
\hline
\end{tabular}

$*$, ** and $* * *$ indicate significance at $\mathrm{P} \leq 0.05,0.01$, and 0.001 .

NS Not significant at $\mathrm{P} \leq 0.05$.

Table 9. Mean of seedling rate, days to heading, and plant height as affected by 20 barley genotypes under El-Serw, Sakha and their combined in the third experiment during 2010/11 growing season

\begin{tabular}{|c|c|c|c|c|c|c|c|c|c|}
\hline \multirow{2}{*}{ Genotype } & \multicolumn{3}{|c|}{ Seedling rate (\%) } & \multicolumn{3}{|c|}{ Days to heading (days) } & \multicolumn{3}{|c|}{ Plant height $(\mathrm{cm})$} \\
\hline & El-Serw & Sakha & Combined & El-Serw & Sakha & Combined & El-Serw & Sakha & Combined \\
\hline 1 & 76.7 & 100.0 & 88.3 & 93.0 & 101.7 & 97.3 & 78.0 & 116.0 & 97.0 \\
\hline 2 & 78.3 & 100.0 & 89.2 & 91.3 & 101.3 & 96.3 & 81.0 & 124.3 & 102.5 \\
\hline 3 & 75.0 & 93.3 & 84.2 & 98.0 & 104.3 & 101.2 & 71.3 & 123.0 & 97.2 \\
\hline 4 & 66.7 & 100.0 & 83.3 & 95.3 & 101.0 & 98.2 & 85.3 & 118.7 & 102.0 \\
\hline 5 & 50.0 & 80.0 & 65.0 & 97.0 & 102.3 & 99.7 & 86.0 & 115.7 & 92.2 \\
\hline 6 & 71.7 & 90.0 & 80.8 & 97.7 & 102.7 & 100.2 & 67.3 & 110.7 & 89.0 \\
\hline 7 & 73.3 & 100.0 & 86.7 & 97.3 & 99.0 & 98.2 & 79.7 & 112.0 & 95.8 \\
\hline 8 & 78.3 & 100.0 & 89.2 & 97.3 & 100.0 & 98.7 & 80.7 & 120.7 & 100.7 \\
\hline 9 & 65.0 & 100.0 & 82.5 & 87.7 & 96.3 & 92.0 & 82.3 & 116.7 & 99.5 \\
\hline 10 & 73.3 & 86.7 & 80.0 & 98.7 & 105.7 & 102.2 & 81.7 & 103.0 & 92.3 \\
\hline 11 & 75.0 & 80.0 & 77.5 & 99.0 & 105.7 & 102.3 & 83.7 & 113.3 & 98.5 \\
\hline 12 & 78.3 & 100.0 & 89.2 & 97.0 & 99.0 & 98.0 & 68.7 & 113.7 & 99.8 \\
\hline 13 & 70.0 & 100.0 & 85.0 & 93.3 & 99.3 & 96.3 & 75.3 & 121.7 & 98.5 \\
\hline 14 & 63.3 & 96.7 & 80.0 & 94.3 & 100.3 & 97.3 & 77.3 & 104.0 & 90.7 \\
\hline 15 & 68.3 & 100.0 & 84.2 & 96.0 & 103.0 & 99.5 & 86.0 & 114.0 & 95.5 \\
\hline 16 & 70.0 & 83.3 & 76.7 & 95.3 & 103.7 & 99.5 & 81.3 & 107.7 & 94.5 \\
\hline 17 & 8.3 & 86.7 & 47.5 & 101.7 & 99.3 & 100.5 & 73.3 & 100.7 & 87.0 \\
\hline 18 & 56.7 & 86.7 & 71.7 & 97.3 & 101.3 & 99.3 & 76.3 & 113.0 & 94.7 \\
\hline 19 & 61.7 & 100.0 & 80.8 & 95.3 & 100.0 & 97.7 & 89.3 & 122.3 & 105.8 \\
\hline 20 & 75.0 & 100.0 & 87.5 & 97.0 & 99.3 & 98.2 & 76.3 & 115.0 & 95.7 \\
\hline Average & 66.75 & 94.17 & 80.47 & 95.98 & 101.26 & 98.63 & 79.04 & 114.4 & 96.45 \\
\hline L.S.D. 0.05 & 13.25 & 9.12 & 8.26 & 4.69 & 3.03 & 2.72 & 6.52 & 12.18 & 6.77 \\
\hline C.V.\% & 12.02 & 5.86 & $8 . .93$ & 2.95 & 1.81 & 2.30 & 5.01 & 6.44 & 6.12 \\
\hline
\end{tabular}


Table 10. Mean squares of No. Tillers and grain yield as affected by 20 barley genotypes under El-Serw, Sakha and their combined in the second experiment during 2010/11 growing season

\begin{tabular}{|c|c|c|c|c|c|c|c|}
\hline \multirow{3}{*}{ S.O.V. } & \multirow{3}{*}{ DF } & \multicolumn{3}{|c|}{ No. Tillers $\mathrm{m}^{-2}$} & \multicolumn{3}{|c|}{ Grain yield $\left(\mathrm{kg} \mathrm{m}^{-2}\right)$} \\
\hline & & \multicolumn{2}{|l|}{ Location } & \multirow{2}{*}{ 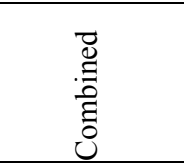 } & \multicolumn{2}{|l|}{ Location } & \multirow{2}{*}{$\begin{array}{l}\text { ठే } \\
\text { हే } \\
\text { है } \\
\text { Uే }\end{array}$} \\
\hline & & El-Serw & Sakha & & El-Serw & Sakha & \\
\hline \multirow{2}{*}{$\begin{array}{l}\text { Rep. } \\
\text { Genotype }\end{array}$} & 2 & $12196.867 * *$ & 894.066 NS & $3259.9 \mathrm{NS}$ & $0.0125 \mathrm{NS}$ & $0.04829 *$ & $0.05352 * *$ \\
\hline & 19 & $10266.119 * * *$ & $9537.90 * * *$ & $16137.04 * * *$ & $0.12658 * * *$ & $0.10128 * * *$ & $0.12446 * * *$ \\
\hline Location & 1 & & & $124163.3^{* * *}$ & & & $13.0020 * * *$ \\
\hline Gen x Loc. & 19 & & & $3666.982 * * *$ & & & $0.10339 * * *$ \\
\hline Error & 78 & & & 1461.609 & & & 0.00905 \\
\hline
\end{tabular}

$*, * *$ and $* * *$ indicate significance at $\mathrm{P} \leq 0.05,0.01$, and 0.001 .

NS Not significant at $\mathrm{P} \leq 0.05$.

\subsubsection{Grain Yield}

Regarding grain yield and its response to salinity stress, in the 2009/10 growing season, high significant differences for grain yield among all 20 barley genotypes was detected as shown in Table 6. Mean values of grain yield per plant under study are found in Table 7 . The maximum grain yield per plant $(36.1 \mathrm{~g})$ was obtained by barley cultivar no.1 (Giza 121) at Sakha followed by barley cultivar no.2 (Giza 123) at El-Serw and the combined $(18.7$ and $25.5 \mathrm{~g})$, respectively, whereas the minimum value $(5.8 \mathrm{~g})$ was obtained by genotype no.10 at El-Serw location, whereas barley genotype no. 14 gave the lowest value at Sakha and the combined recording 10.7 and 8.9 $\mathrm{g}$, respectively. Moreover, high significant differences for grain yield among all 20 barley genotypes were detected (Table 10), in the 2010/11 growing season and the mean values of grain yield are presented in Table 11. The maximum grain yield was obtained by barley cultivar no.2 (Giza 123) at El-Serw and combined ( 0.98 and $1.11 \mathrm{Kg}$ $\left.\mathrm{m}^{-1}\right)$, while genotype no.20 gave the maximum grain yield $\left(1.60 \mathrm{Kg} \mathrm{m}^{-2}\right)$ at Sakha. On the other hand, the minimum value $\left(0.17 \mathrm{Kg} \mathrm{m}^{-2}\right)$ was obtained by genotype no.17 at El-Serw location, while barley genotype no.5 (Giza 132) gave the lowest value at Sakha and combined recording $\left(0.97\right.$ and $\left.0.66 \mathrm{Kg} \mathrm{m}^{-2}\right)$, respectively. These results are in agreement with those reported by (Ahmed et al., 2001; Ahmed et al., 2003; Mariey, 2004; Oraby et al., 2005). The combined analysis (Table 11) showed high significant effect of the interaction between locations (L) and genotypes $(\mathrm{GxL})$. It was also concluded from this investigation that there was an interaction between genotypes and environment, and there were two barley genotypes including genotypes no. 9 (Saiko) from (France) and barley genotype no.12 (line from Cyprus), out yielded the check cultivars (Giza 123 and Giza 124) in grain yield, significantly. They also have some other advantages such as earliness, plant height, and number of tillers $\mathrm{m}^{-2}$. Therefore, it is suggested that these two genotypes need more genetic stability studies to be grown in such saline soils and could be used as new tolerant genotypes for the saline breeding programs. We also consider barley genotype no.17 (from ACSAD) as sensitive for salinity stress and can be used in barley breeding program and molecular studies as well. 
Table 11. Mean of No. tillers and grain yield for 20 barley genotypes under El-Serw, Sakha and their combined in the second experiment during 2010/11 growing season

\begin{tabular}{llllllll}
\hline \multirow{2}{*}{ Genotype } & \multicolumn{2}{l}{ No. Tillers $\mathrm{m}^{-2}$} & & \multicolumn{3}{c}{ Grain yield $\left(\mathrm{kg} \mathrm{m}^{-2}\right)$} \\
\cline { 2 - 5 } \cline { 6 - 7 } & El-Serw & Sakha & Combined & & El-Serw & Sakha & Combined \\
\hline 1 & 437.0 & 597.0 & 517.0 & & 0.55 & 1.53 & 1.04 \\
2 & 467.0 & 479.0 & 473.0 & & 0.98 & 1.23 & 1.11 \\
3 & 370.0 & 461.0 & 415.5 & & 0.62 & 1.27 & 0.94 \\
4 & 297.0 & 400.0 & 348.5 & & 0.58 & 1.33 & 0.96 \\
5 & 243.0 & 384.0 & 313.5 & & 0.35 & 0.97 & 0.66 \\
6 & 379.0 & 379.0 & 379.0 & & 0.63 & 1.23 & 0.93 \\
7 & 367.0 & 423.0 & 395.0 & & 0.98 & 1.17 & 1.08 \\
8 & 430.0 & 453.0 & 441.5 & & 0.42 & 1.10 & 0.76 \\
9 & 297.0 & 451.0 & 374.0 & & 0.35 & 1.10 & 0.73 \\
10 & 317.0 & 376.0 & 346.5 & & 0.43 & 1.00 & 0.72 \\
11 & 333.0 & 373.0 & 353.0 & & 0.58 & 1.15 & 0.87 \\
12 & 453.0 & 456.0 & 454.5 & & 0.63 & 1.57 & 1.10 \\
13 & 390.0 & 395.0 & 392.5 & & 0.68 & 1.00 & 0.84 \\
14 & 380.0 & 419.0 & 399.5 & & 0.57 & 1.10 & 0.83 \\
15 & 395.0 & 477.0 & 436.0 & & 0.73 & 1.10 & 0.92 \\
16 & 343.0 & 401.0 & 372.0 & & 0.58 & 1.07 & 0.83 \\
17 & 327.0 & 367.0 & 347.0 & & 0.17 & 1.23 & 0.70 \\
18 & 299.0 & 353.0 & 326.0 & & 0.33 & 1.18 & 0.76 \\
19 & 343.0 & 451.0 & 397.0 & & 0.33 & 1.33 & 0.83 \\
20 & 397.0 & 463.0 & 430.0 & & 0.58 & 1.60 & 1.09 \\
Average & 363.2 & 427.9 & 395.6 & & 0.55 & 1.21 & 0.89 \\
L.S.D. 0.05 & 63.3 & 52.7 & 43.9 & & 0.115 & 0.191 & 0.109 \\
C.V.\% & 10.53 & 7.45 & 9.66 & & 12.5 & 9.53 & 10.76 \\
\hline
\end{tabular}

\subsection{Molecular Analysis}

Out of the 10 used SSR primer pairs, only six primers (Bmac0209, Bmac 0316, Scssr 03907, Bmag770, HVM67 and HVHOTRI) generated clear patterns with high polymorphism. Three primers showed monomorphic band profiles (Scssr 0013, Bmag 0387 and HVHVA1), and one primer (HVAMY2) did not show any amplification even when repeated twice and did not generate any bands, therefore it was discarded (Table 12).

Table 12. Barley SSR primers, their amplified fragments, polymorphic and the polymorphism parentage

\begin{tabular}{llll}
\hline \multirow{2}{*}{ Primer } & Amplified fragments & \multirow{2}{*}{ Polymorphism \% } \\
\cline { 2 - 3 } & Total (T) & Polymorphic & 50 \\
\hline HVHOTR1 & 2 & 2 & 66 \\
HVM67 & 3 & 0 & 0 \\
HVHVA1 & 1 & 0 & 0 \\
Scssr0013 & 1 & 3 & 100 \\
Scssr03907 & 3 & 4 & 80 \\
Bmac0316 & 5 & 3 & 100 \\
Bmac0209 & 3 & 4 & 100 \\
Bmag770 & 4 & 0 & 0 \\
Bmag0387 & 1 & 0 & 0 \\
HVAMY2 & 0 & & \\
\hline
\end{tabular}




\subsubsection{Diversity Analysis}

The six discriminatory primer pairs were used to evaluate the genetic diversity and association of salt tolerance in 20 barley genotypes. These primer pairs revealed a total of 23 alleles ranging from two to five alleles per locus (Table 12). For all tested genotypes, the highest number of bands was developed by the primer Bmac0316 (five bands), followed by Bmag770 (four bands). Moreover, the primer Bmac0209 showed unambiguous scorable bands with the 20 barley genotypes with varying responses to salinity stress, it showed three bands with $100 \%$ polymorphism. Also, the primer Scssr03907 gave fewer bands number but have high polymorphic percentage; it showed three bands, with $100 \%$ polymorphism, while the marker HVM67 produced three bands with $66 \%$ polymorphism. However the lowest number of bands was found by the primer HVHOTRI which gave two bands with $50 \%$ polymorphism.

\subsubsection{Cluster Analysis}

Based on phylogenic trees using rooted neighbor joining (NJ) the dendrogram (Figure 1) constructed with SSR markers data showed four clusters. All the tolerant genotypes and some moderately tolerant ones were found in closely related three clusters, which consisted of the tolerant genotypes. The first cluster included (California Mariout, G. 123, Line 8, Line 9, Saiko and Giza 2000), while the other two clusters included the moderate tolerant genotypes in two clusters; the first cluster included Rihane- 03 and Line 1 and second cluster included two genotypes (line 2 and line 4). On the other hand, the most closely related two clusters consisted of Giza 124 only and the other cluster consisted of all the sensitive and moderate sensitive genotypes together. The second cluster divided into two subgroups. The first subgroup consisted of Giza 121 only and the second subgroup consisted of sensitive and moderate genotypes. This cluster could be divided into two subgroups; the first subgroup consisted of sensitive genotypes as Line 5, Giza 132, CC89, Dier Alla, Beecher and Line 6, while the second subgroup included two genotypes (Line 3 and Line 7) as moderate sensitive genotypes. Considering the alleles produced with respect to California Mariout and G. 123, all primer alleles were linked to genotypes that were tolerant or moderately tolerant to salt stress. 


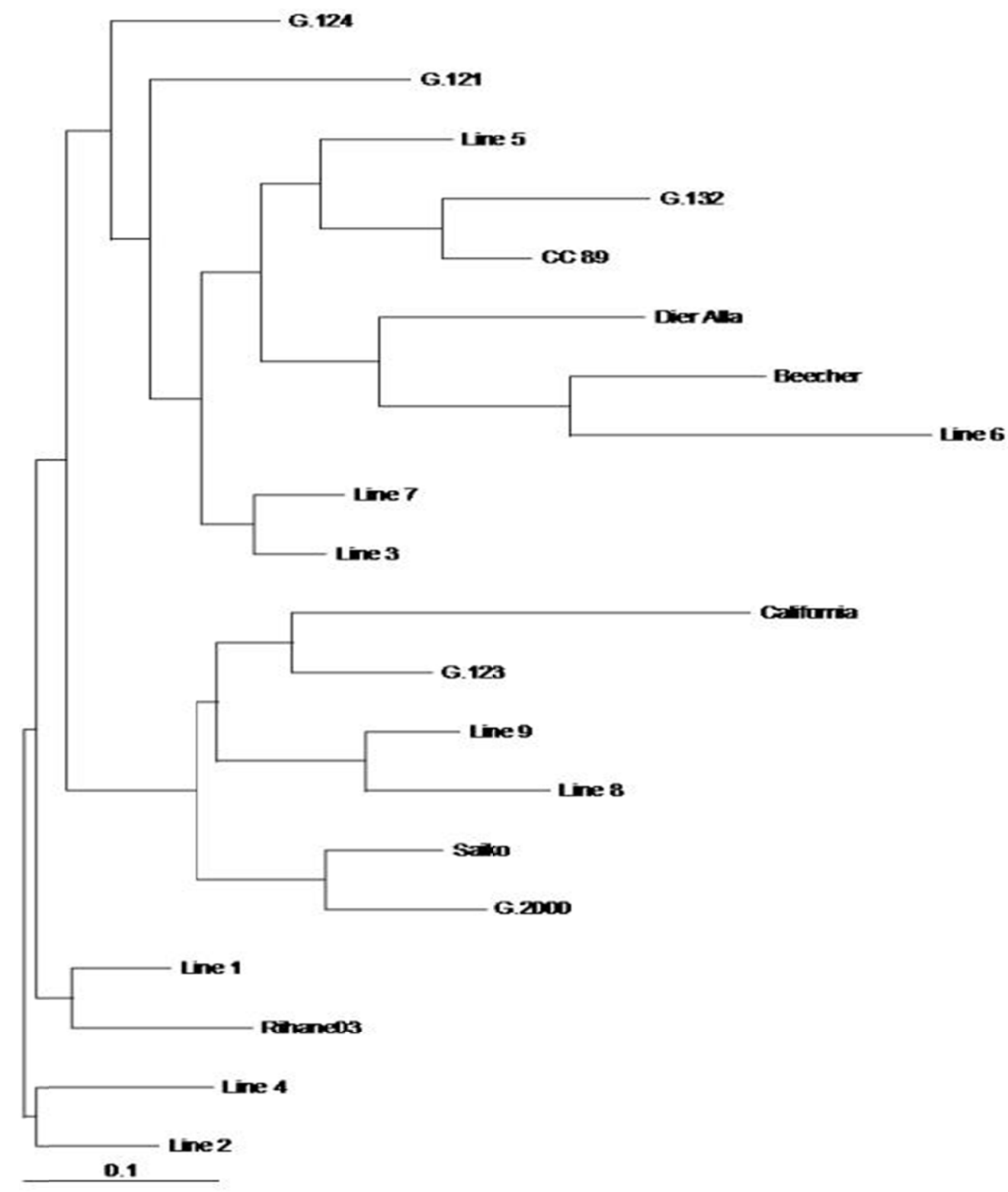

Figure 1. Rooted neighbor joining (NJ) phylogenetic tree for 20 barley genotypes based on SSR make

\subsubsection{Genetic Similarity}

The genetic similarity matrix was established by simple matching coefficient using the data generated by the six expressing primers. These primers enabled us to discriminate all the genotypes and to study the genetic variability for salt tolerance among the improved varieties and lines. The similarity index showed more relation and close in most tolerant genotypes and they are more diverged than other sensitive genotypes. Regarding the tolerant genotypes they were classified into two clusters, the first cluster included the tolerant genotypes (California Mariout, G. 123, Line 8, Line 9, Saiko and Giza 2000) which were similar to each other and their GS ranged from 0.53 to $0.86 \%$. However, the second cluster included Rihane- 03 and Line1, these two genotypes were genetically very similar to each other (GS=0.86\%), also the two genotypes Saiko and Giza 2000 were very similar to each other $(\mathrm{GS}=0.86 \%)$. On the other hand, the subgroup clusters included the sensitive and moderate genotypes including two subgroup clusters. In the second subgroup cluster the two genotypes (line 3 and line 7) were genetically very similar to each other ( $\mathrm{GS}=0.92 \%$ ), and Giza 121 was similar to the sensitive group with GS ranging from $0.47 \%$ between Giza 121 and line 6 to $0.82 \%$ between Giza 121 and Line7. Also Giza 124 was similar to the sensitive genotype line 6 with $(\mathrm{GS}=39 \%)$. Regarding the relativeness between the most tolerant genotype California Mariout and the most two sensitive genotypes, line 6 with GS $=0.35 \%$ and Beecher with $\mathrm{GS}=0.31 \%$. We could conclude that there was swerved between tolerant group and sensitive group. 
Markers validation in independent genotypes of different genetic background is essential in determining the effectiveness and reliability of the markers to predict phenotypic (Lin et al., 1998; Koyama et al., 2001; Collins et al., 2003; Cakir et al., 2003), which indicates that SSR marker, could be used in routine screening for marker-assisted selection (MAS). Markers should also be validated by testing for the presence of the markers on a range of cultivars and other important genotypes. Therefore, marker-assisted selection for salinity tolerance could be genotype resistance specific. Interestingly enough, our findings indicated that the potential efficacy of highly informative SSR markers were efficient screening for brewing genotypes in barley. Genetic relationships among barley varieties revealed by genetic similarity at SSR levels were in agreement with their roles in agricultural production and breeding (Qian et al., 2011). As a good confirmation, Karakousis et al. (2003) argued the usefulness of polymorphic SSR markers for the discrimination of breeding material in Australian barley. In barley, important traits such as salt tolerance are controlled by polygenes with additive and dominant effects that are described by quantitative trait loci (QTLs) (Eilles et al., 2000) as salt tolerance is controlled by a variety of mechanisms.

The presence of moderately tolerant to highly sensitive genotypes in the same cluster group confirms the presence of polygene controlling salt tolerance. Also cluster of all salt tolerant diverse genotypes at seedling stage with varying marker response to cluster groups indicates that some markers are more suitable for use in marker-assisted breeding than the other and that HVHOTRI was best in marker-assisted selection followed by Bmac0316, HVM67 and Bmac 0209. These results are in a good harmony with those reported by (Eleuch et al., 2008; Chaabane et al., 2009; Aliyu et al., 2011). For the present study we can consider that these genotypes which showed salt tolerance could serve as potentially novel germplasm that could be exploited for the development of new breeding lines with high level of salinity tolerance and to accelerate genetic advancement in barley and cost-efficient than conventional screening under saline field conditions. The productivity of SSR markers may be due to the possibility of amplification of the different size fragments from different regions of the genome or may be dependent on the genotypes; it clearly indicated that there were correlations among the salt tolerant genotypes.

\section{References}

Ahmad, A. N., Intshar, U. H. J., Shamshad, A., \& Muhammad, A. (2003). Effects of $\mathrm{Na}, \mathrm{SO}_{2}$ and $\mathrm{NaCl}$ salinity levels on different yield parameters of barley genotypes. Intl. J. Agric. Biol., 5(2), 157-159.

Ahmed, I. A., El-Hag, A. A., Amer, K. A., El-Moselhy, M. A., \& Said, M. A. (2001). Evaluation of some barley genotypes for salt tolerance. National Coordination Meeting, Egypt, ARC, Cairo, Sept., 2-4.

Aliyu, R., Adamu, A. K., Muazu, S., Alonge, S. O., \& Gregorio, G. B. (2011). Tagging and validation of SSR markers to salinity tolerance QTLs in Rice (Oryza spp.). International Conference on Biology, Environment and Chemistry (IPCBEE vol.1).

Becker, J., \& Heun, M. (1995). Barley microsatellites: allele variation and mapping. Plant Mol Biol., 27, 835-845. http://dx.doi.org/10.1007/BF00020238

Bengtsson, B. O. (1992). Barley Genetics. Trends in Genetics, 8, 3-5. http://dx.doi.org/10.1016/0168-9525(92)90003-M

Bennett, M. D., \& Smith, J. B. (1976). Nuclear DNA amounts in angiosperms. Philos. Trans. R. Soc. Lond. Ser., 274, 227-274. http://dx.doi.org/10.1098/rstb.1976.0044

Black, C. A., Evans, D. D., White, J. L., Ensminger, L. E., \& Clark, F. E. (1965). Methods of Soil Analysis. Part 2. Agron. Monogr. 9. Wisconsin, USA: American Society of Agronomy, Madison.

Cakir, M., Gupta, S., Platz, G. J., Ablett, G. A., Loughman, R., Emebiri, L. C., ... Appels, R. (2003). Mapping and validation of the genes for resistance to Pyrenophora teres f. teres in Barley (Hordeum vulgareL.). Aust $J$ Agric Res., 54, 1369-1377. http://dx.doi.org/10.1071/AR02229

Chaabane, R., El Felah, M., Ben Salah, H., Ben Naceur, M., Abdelly, C., Dalila, R., ... Saker, M. (2009). Molecular Characterization of Tunisian barley (Hordeum vulgare L.) genotypes using microsatellites (SSRs) markers. European Journal of Scientific Research, 36(1), 6-15

Collins, H. M., Panozzo, F., Logue, S. J., Jefferies, S. P., \& Barr, A. R. (2003). Mapping and validation of chromosome regions associated with high malt extract in barley (Hordeum vulgare L.). Aust. J. Agric. Res., 54, 1223-1240. http://dx.doi.org/10.1071/AR02201

Doyle, J. J., \& Doyle, J. L. (1990). Isolation of plant DNA from fresh tissue. Focus, 12, 13-15.

Duncan. (1955). Multiple range and multiple F-test. Biometrics, 11, 1-42. 
EI-Lakany, M. H., Hassan, M. N., Ahmed, A. M., \& Mounir, M. (1986). Salt affected soils and marshes in Egypt; their possible use for forages and fuel production. Reclamation and Revegetation Research, 5, 49-58.

Eleuch, L., Jilal, A., Grando, S., Ceccarelli, S., Schmising, M. K., Tsujimoto, H., ... Baum, M. (2008). Genetic diversity and association analysis for salinity tolerance, heading date and plant height of barley germplasm using simple sequence repeat markers. J. Integr. Plant Biol., 50, 1004-1014. http://dx.doi.org/10.1111/j.1744-7909.2008.00670.x

Ellis, R. P., Forster, B. P., Robinson, D., Handley, L. L., Gordon, D. C., Russell, J. R. ... Powell, W. (2000). Wild barley: a source of genes for crop improvement in the $21^{\text {st }}$ century? $J$. Exp. Bot., 51, 9-17. http://dx.doi.org/10.1093/jexbot/51.342.9

Ghassemi, F., Jakeman, A. J., \& Nix, H. A. (1995). Salinisation of land and water resources: Human causes, extent, management and case studies. Sydney, Australia: UNSW Press, and CAB International, Wallingford, UKAgr. Expt.

Hamza, S., Hamida, W. B., Rebai, A., \& Harrabi, M. (2004). SSR-based genetic diversity assessment among Tunisian winter barley and relationship with morphological traits. Euphytica, 135, 107-118. http://dx.doi.org/10.1023/B:EUPH.0000009547.65808.bf

Hayden, M. J., Stephenson, P., Logojan, A. M., Khatkar, D., Rogers, C., Elsden, J., ... Sharp, P. J. (2006). Development and genetic mapping of sequence-tagged microsatellites (STMs) in bread wheat (Triticum aestivum L.). Theor. Appl. Genet., 113, 1271-1281. http://dx.doi.org/10.1007/s00122-006-0381-4

Hayes, R. B., Zhang, L., Yin, S., Swenberg, J. A., Xi, L., Wiencke, J., ... Smith, M. T. (2000). Genotoxic markers among butadiene polymer workers in China. Carcinogenesis, 21(1), $55-62$. http://dx.doi.org/10.1093/carcin/21.1.55

Hearnden, P. R., Eckermann, P. J., McMichael, G. L., Hayden, M. J., Eglinton, J. K., Chalmers, K. J. (2007). A genetic map of 1000 SSR and DArT loci in a wide barley cross. Theor. Appl. Genet., 115(3), $383-391$. http://dx.doi.org/10.1007/s00122-007-0572-7

Ivandic, V., Hackett, C. A., Nevo, E., Keith, R., Thomas, W. T., \& Forster, B. P. (2002). Analysis of simple sequence repeats (SSRs) in wild barley from the Fertile Crescent: associations with ecology, geography and flowering time. Plant Mol Biol., 48, 511-27. http://dx.doi.org/10.1023/A:1014875800036

Karakousis, A. (2002). The development, identification and application of SSR markers for use in Australian barley (Hordeum vulgare L.) breeding programs. PhD thesis, Department of Plant Science, University of Adelaide, Australia.

Karakousis, A., Gustafson. J. P., Chalmers. K. J., Barr. A. R., \& Langridge, P. (2003). A consensus map of barley integrating SSR, RFLP, and AFLP markers. Aus. J. Agr. Res., 54, 1173-1185. http://dx.doi.org/10.1071/AR02177

Kleinhofs, A., \& Graner, A. (2001). An integrated map of the barley genome. In R. L. Phillips, \& I. K. Vasil (Eds.), DNA-based Markers in Plants (2nd ed., pp. 187-200). Dordrecht: Kluwer Academic Publishers. http://dx.doi.org/10.1007/978-94-015-9815-6_12

Koyama, M. L., Aurora, L., Robert, M. D. K., Timothy, J. F., \& Anthony, R. Y. (2001). Quantitative trait loci for component physiological traits determining salt tolerance in rice. Plant Physiol., 125, 406-422. http://dx.doi.org/10.1104/pp.125.1.406

Lin, H., Yanagihara. S., \& Zhuang, J. (1998). Identification of QTL for salt tolerance in rice via molecular markers. Chinese Journal of Rice Science, 12(2), 72-78.

Liu, Z. W., Biyashev, R. M., \& Maroof, M. A. S. (1996). Development of simple sequence repeat markers and their integration into a barley linkage map. Theor. Appl. Genet., 93, 869-876. http://dx.doi.org/10.1007/BF00224088

Lynch, M. (1990). The similarity index and DNA fingerprinting. Molecular Biology and Evolution, 7, 478-484.

Macaulay, M., Ramsay, L., Powell, W., \& Waugh, R. (2001). A representative, highly informative 'genotyping set' of barley SSRs. Theor. Appl. Genet., 102, 801-809. http://dx.doi.org/10.1007/s001220000487

Mariey, A. S. (2004). Genetical and molecular studies on barley salt tolerance. M.Sc. Thesis, Tanta Univ., Egypt.

Munns, R., \& Tester, M. (2008). Mechanisms of salinity tolerance. Annu. Rev. Plant Biol., 59, 651-681. http://dx.doi.org/10.1146/annurev.arplant.59.032607.092911 
Naseer, S. H., Nisar, A., \& Ashraf, M. (2001). Effect of salt stress on germination and seedling growth of salt stress in the selection of salt tolerance hybrids in barley (Hordeum vulgare L. ). Pak. J. Biol. Sci., 4(3), 359-360. http://dx.doi.org/10.3923/pjbs.2001.359.360

Nei, M., \& Li, W. H. (1979). Mathematical models for studying genetic variation in terms of restriction endonucleases. Proc Natl. Acad. Sci., 76, 5269-5273. http://dx.doi.org/10.1073/pnas.76.10.5269

Oraby, H. F., Ransom, C. B., Kravchenko, A. N., \& Sticklen, M. B. (2005). Barley HVA1 Gene Confers Salt Tolerance in R3 Transgenic Oat 2005. Crop Sci., 45, 2218-2227. http://dx.doi.org/10.2135/cropsci2004-0605

Ordon, F., Friedt, W., Scheurer, K., Pellio, B., Werner, K., Neuhaus, G., ... Graner, A. (2004). Molecular markers in breeding for virus resistance in barley. J. Appl. Genet., 45(2), 145-159.

Pillen, K., Binder, A., Kreuzkam, B., Ramsay, L., Waugh, R., Forster, J., ... Leon, J. (2000). Mapping new EMBL-derived barley microsatellites and their use in differentiating German barley cultivars. Theor. Appl. Genetics, 101, 652-660. http://dx.doi.org/10.1007/s001220051527

Piper, C. S. (1950). Soil and Plant Analysis. Australia: Adelaide University Hassel Press.

Powell, W. (1996). Molecular biology. In S. W. H. Macfarlane, \& T. D. Heilbron (Eds.), Scottish Crop Research Institute Annual Report 1996/97 (pp. 79-82). Dundee: Burns and Harris.

Qian, G., Ping, J., Wang, D., Zhang, Z., \& Luo, S. (2011). Malt genotypic screening of polymorphism information content (PIC) of PCR-based marker in barley, based on physiological traits. Molecular Biology, 1, 101-106.

Ramsay, L., Macaulay, M., Ivanissevich, S. D., MacLean, K., Cardle, L., Fuller, J., ... Waugh, R. (2000). A simple sequence repeat-based linkage map of barley. Genetics, 156, 1997-2005.

Röder, M. S., Huang, X. Q., \& Ganal, M. W. (2004). Wheat microsatellites: potential and implications. In H. Lörz, \& G. Wenzel (Eds.), Biotechnology in agriculture and forestry: molecular marker systems (pp. 255-266). Springer Verlag.

Rohlf, F. J. (1998). NTSYS-pc version 2.02j. Numerical taxonomy and multivariate analysis system. Exeter software, Setauket: New York.

Russell, J. R., Ellis, R. P., Thomas, W. B., Waugh, R., Provan, J., Booth, A., ... Powell, W. (2000). A retrospective analysis of spring barley germplasm development from 'foundation genotypes' to currently successful cultivars. Mol. Breed., 6, 553-568. http://dx.doi.org/10.1023/A:1011372312962

Saghai, M. A., Biyashev, R. M., Yang, G. P., Zhang, Q., \& Allard, R. W. (1994). Extraordinarily polymorphic microsatellite DNA in barley: species diversity, chromosomal locations, and population dynamics. Proc. Natl. Acad. Sci., 91, 5466-5470. http://dx.doi.org/10.1073/pnas.91.12.5466

Saker, M. M. (2005). Mapping RAPD and SSR markers linked to net blotch resistance gene in barley. Arab J. Biotechnology, 8, 369-378.

Snedecor, C. W., \& Cochran, W. G. (1969). Statistical Methods (6th ed.). Iowa State Univ. Press, Ames, Iowa, USA.

Struss, D. (1998). The use of microsatellite markers for detection of genetic diversity in barley populations. Theor. Appl. Genet., 97, 308-315. http://dx.doi.org/10.1007/s001220050900

Taghipour, F., \& Salehi, M. (2008). The study of salt tolerance in Iranian barley (Hordeum vulgare L.) genotypes in seedling growth stage. Am Eu J. Agric. Environ. Sci., 4, 525-529.

Varshney, R. K., Marcel, T. C., Ramsay, L., Russell, J., Röder, M. S., Stein, N., ... Graner, A. (2007). A high density barley microsatellite consensus map with 775 SSR loci. Theoretical and Applied Genetics, 114(6), 1091-1103. http://dx.doi.org/10.1007/s00122-007-0503-7

Werner, K., Friedt, W., \& Ordon, F. (2007). Localisation and combination of resistance genes against soil-borne viruses of barley (BaMMV, BaYMV) using doubled haploids and molecular markers. Euphytica, 158(3), 323-329. http://dx.doi.org/10.1007/s10681-006-9206-4

\section{Copyrights}

Copyright for this article is retained by the author(s), with first publication rights granted to the journal.

This is an open-access article distributed under the terms and conditions of the Creative Commons Attribution license (http://creativecommons.org/licenses/by/3.0/). 